\title{
Effect of Mycorrhizal Fungi on the Growth of Ailanthus excelsa Seedlings Grown in Different Potting Media under Nursery Condition
}

\author{
Ishwar Anand ${ }^{1}$, M. K. Singh ${ }^{2 *}$, R. K. Chugh ${ }^{2}$ and Sanjay Kumar ${ }^{3}$ \\ ${ }^{1}$ Department of Forestry, ${ }^{2}$ Department of Plant Pathology, ${ }^{3}$ Department of Agriculture \\ Economics, Chaudhary Charan Singh Haryana Agircultural University, Hisar \\ *Corresponding author
}

\section{A B S T R A C T}

Keywords

Acaulospora scrobiculata,

Glomus

intraradices,

Ailanthus excelsa,

Potting media

Article Info

Accepted:

17 June 2020

Available Online:

10 July 2020
An experiment was conducted in nursery condition in Department of Forestry, CCSHAU, Hisar. Pots were filled with different soils media containing field soil (FS), farm yard manure (FYM) and pond silt (PS) were inoculated with two mycorrhizal fungi i.e. Glomus intraradices (G.I) sand Acaulospora scrobiculata (A.S). Seeds of Ailanthus excelsa were sown in pots for studied growth parameters i.e shoot and root length, collar diameter, number of leaves, root and shoot biomass and root colonization, mycorrhizal dependency and seedling quality index after three and six months of seeds sown in the pots and found that potting media containing FS + FYM with individual mycorrhiza fungi performed better than other treatments.

\section{Introduction}

Ailanthus excelsa (Roxb) commonly called "Tree of Heaven" belongs to the family Simaroubaceae. It is a deciduous multipurpose tree grows well in arid and semi arid regions, its grows well in all types of soil but performed better in porous sandy-loams soil. Its leaves can feed to ruminant animals in the month of April to June and November to January in drought condition. It is one of the most important tree species in arid ecosystem to sustain the productivity of animals like goat and sheep (Jat et al., 2011). It is cultivated for anti-erosion purposes in arid and semi arid regions of the country. It is usually absent in heavy clay soils, water logged area and high rainfall area with poor drainage.

For the successful plantation of Ardu in arid and semi arid region, it is necessary that its roots can be inoculated with mycorrhizal fungi before planting out from nursery because these fungi play an important role in increases the absorption area of trees roots and solubilize the essential plant nutrients.

Arbuscular mycorrhizal fungi (AMF) are obligate biotrophs, which can form mutualistic symbioses with the roots of plant 
species (Giovannetti, 2008). AMF symbiosis can develop extra-radical mycelia, which disperse outside the roots to have access to a greater quantity of water and soil minerals for the host plants. In return, these mycorrhizal fungi receive plant carbohydrates for the completion of its life cycle (Genre and Bonfante, 2010). These fungi are associated with enhance the growth of many plant species by increased in nutrients uptake resulting in increased growth of plants (Miransari, 2010), the beneficial effects of AMF in improving tolerance to environmental stress conditions (Dell'Amico et al., 2002). The mycorrhizae help to enhance the growth of seedlings and survivals under nursery conditions are well documented (Guissou et al., 2016).

keeping in view the above facts the experiment was conducted to study the effect of mycorrhizal fungi on the seedlings of Ailanthus excelsa grown in different potting media under nursery condition.

\section{Materials and Methods}

\section{Climate and Weather}

The climate of Hisar (Haryana) is semi-arid with hot and dry desiccating winds accompanied by frequent dust storms with high velocity in summer months, severe cold during in winter months and humid warm during monsoon rainy season. The mean monthly maximum and minimum temperature sometimes exceeds $48^{\circ} \mathrm{C}$ in hot summer days. Relative humidity varies from 5 to 100 percent, while temperature below freezing point accompanied by frost in winter is usually experienced in this region.

\section{Mycorrhizal inoculum}

AMF under studied were multiplied in sterile soil through inoculation of wheat plant roots separately with Glomus intraradices (G.I) and Acaulospora scrobiculata (A.S). Soil and rootlets from root horizon of Glomus intraradices and Acaulospora scrobiculata inoculated wheat plants were used to inoculate Ailanthus excelsa seeds in twelve treatments with various potting media. Mycorrhizal evaluation/colonization in roots of Ailanthus excelsa seedlings were described previously by Phillips and Hayman, (1970).

\section{Mycorrhizal evaluation in roots}

Roots of mycorrhizal segments were stained by following the procedure of Phillips and Hayman (1970). Infested roots of Ailanthus excelsa with AM fungi were cut into small pieces about $2 \mathrm{~cm}$ in length and heated at $90^{\circ} \mathrm{C}$ in $10 \% \mathrm{KOH}$ solution for an hour over the hot plate, afterwards these root pieces of each treatment were washed with fresh $\mathrm{KOH}$ solution and immersed in $10 \% \mathrm{H}_{2} \mathrm{O}_{2}$ solution for 30 minutes.

These rootlets were washed with distilled water to remove hydrogen peroxide and $\mathrm{HCl}$ contamination. Finally, these rootlets were stained by simmering for 10 minutes in $0.05 \%$ trypan blue and examined under microscope for presence of hyphae, vesicules or arbuscules or any combination of these structures AM fungi.

\section{Preparation of soil}

Field soil (FS) were collected from Balsamand Research Farm, CCSHAU, Hisar and mixed with well rotted Farm Yard Manure (FYM) and pond silt (PS) in 1:1:1 ratio. These potting mixtures were autoclaved at $120^{\circ} \mathrm{C}$ for 30 minutes for disinfectant. Seeds of Ailanthus excelsa collected from plus tree at Balsamand Research Farm were sown about 2-3 cm deep in polybags of $1 \mathrm{~kg}$ capacity with mixing of $10 \mathrm{~g} / \mathrm{kg}$ inoculums of AM fungi include rhizospheric soil and roots 
to studied the growth parameters were studied after three and six months of sowing i.e. shoot and root length, collar diameter, number of leaves, root and shoot biomass and AM fungi root Colonization Index (CI), Mycorrhizial dependency (MD) and seedlings quality index (SQI).

The various combination of potting mixture filled in polybags were Contol (only FS), FS + G.I, FS + A.S, FS + FYM (1:1), FS oil + PS (1:1), FS + FYM + G.I (1:1), FS + FYM + A.S (1:1), FS + PS + G.I (1:1), FS + PS+ A.S $(1: 1), F S+P S+F Y M+$ G.I $(1: 1: 1), F S+P S$ $+\mathrm{FYM}+\mathrm{A} . \mathrm{S}(1: 1: 1)$ and FS + PS + FYM + A.S + G.I (1:1:1) and observations on root colonization were recorded by the procedure given by Giovannetti and Mosse (1980).

\section{Mycorrhizal dependency (MD)}

Mycorrhizal dependency was calculated in terms of plant growth using dry weights of individual plants $(\mathrm{M})$, and mean dry weight of corresponding non-mycorrhizal plants (NM) given by Plenchetteet. al. (1983).

Mycorrhizal dependency $(\mathrm{MD})(\%)=[(\mathrm{M}-$ $\mathrm{NM}) / \mathrm{M}] \times 100$

\section{Seedling quality index (SQI)}

Seedling quality index was calculated by using plant height, plant dry weights and collar diameter using formula outlined by Dickson (1960).

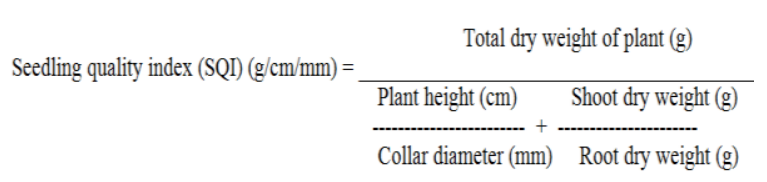

\section{Statistics analysis}

Seedlings of Ailanthus excelsa were maintained in nursery condition in CRD with twelve treatments inoculated with two AM fungi. Ten replications with three plants per replications were used for each treatment. Statistical procedures were carried out with the Software Package OPSTAT developed by CCSHAU, Hisar with significant differences were based on $5 \%$.

\section{Results and Discussion}

The perusal of data in Table-1 indicated that root growth parameters of Ailanthus excelsa like root length, fresh root weight and dry root weight were found significantly higher in treatment containing FS $+\mathrm{FYM}+\mathrm{A} . \mathrm{S}$ whereas, shoot parameters like shoot length, fresh shoot weight dry shoot weight, collar diameter and number of leaves were found significantly higher in treatment containing FS + FYM + G.I as compared with control after three and six months of growth of Ailanthus excelsa seedlings and other treatments under studied. Growth parameters of Azadirachta indica was found significantly higher when treated with mycorrhiza fungi over control reported by Banerjee et. al (2013). Basumatary et. al., (2014) also reported that increase in growth parameters like shoot length, diameter and biomass yield in rubber tree seedlings inoculated with Acaulospora and Glomus over control. Similar observation also reported by Berdeni et. al., (2018) in apple seedlings treated with AM fungi. Chen et al., (2017) observed that Pistacia seedlings growth was improved when inoculated with $G$. mosseae. Similar observation were also reported by Chu (1999) in E. oleracea seedlings inoculated with Scutellispora gilmorei. Application of Rhizofagus clarum and Glomus etunicatum in dry matter production of star fruit reported by Filho et. al., (2017). Maximum increase in leaf area, shoot length, collar diameter was found in tree species treated with Glomus mosseae over control investigated by Ghosh and Verma (2011). IIangamudali and Senarathne (2016) found that number, 
volume, and dry weight of primary, secondary, tertiary and quaternary root was increased in coconut seedlings treated with mycorrhizae. AM fungi inoculated plants had better growth than uninoculated plants observed by Mohan and Sandeep (2015). AM fungi improve seedlings growth and survival reported by Mwangi et al., (2017).

In this experiment significantly higher growth after three and six months of Ailanthus excelsa were recorded with potting media containing FS + FYM than other potting media indicating that organic matter play an important role in the survival and growth of seedlings of tree species.

Ahmadloo et al., (2012) found that cattle manure and decomposed litter play an important role in germination, shoot length, collar diameter etc of Cupressus species. Annapurna et al., (2007) also suggested that different ratio of sand, soil and compost effect the growth of Santalum album seedings. Seedlings quality of Azadirachta indica was found better when grown in potting mixture containing different ratio of organic matter reported by Biradar et al., (2001). Mulugeta (2014) suggested that survival and growth of seedlings were also affected by different potting mixtures containing organic matter. Similar observation also reported by Han et al., (2016) in yellow poplar seedlings, Bhasotiya and Tandel (2017) in Ailanthus excelsa seedlings.

The data pertaining to colonization index (CI), mycorrhizal dependency (MD) and seedling quality index (SQI) is given in Table-2. The significantly higher values of colonization index reported in FS + FYM+ G.I followed by FS + FYM+ A.S at harvest and found minimum in dual inoculated treatment i.e., FS + PS + FYM + A.S + G.I after three and six months of seedlings growth. The AM fungi inoculated seedlings recorded greater root colonization than uninoculated plant in Acacia nilotica (Mehrotra et al., 1999) in Tecomela undulata. Similar result also reported by $\mathrm{Bi}$ et al., (2018) who found higher colonization index in Rhizophagus intraradices than Funneliformis mosseae and dual inoculation in Amygdalus pedunculata.

Saritha et.al,. (2014) also found highest colonization of sapota plant treated with Glomus mosseae than control. Jasper et al., (1989) observed maximum colonization in Glomus sp. inoculated plants than $S$. calospora whereas no inoculation was found in uninoculated plants of Acacia sp. Kaushik et al., (2000) found that Glomus mosseae inoculation on root pathogens in Acacia nilotica and Dalbergia sissoo seedlings decreased the disease intensity and increased the $\mathrm{N}, \mathrm{P}, \mathrm{K}$ content in roots and shoots. The mycorrhizal percentage of re-watered plants was similar to that of well-watered individuals.

Drought had promoted leaf shedding in Dalbergia sissoo, in all the stressed conditions of mycorrhizal and nonmycorrhizal seedlings. Shukla et al., (2017) found higher colonization in bio-inoculated mycorrhizal Acacia nilotica, Casuarina equisetifolia, Eucalyptus tereticornis and Dalbergia sissoo plants. The mycorrhizal dependency found highest in FS + FYM + Acaulospora scrobiculata which is statistically at par with FS + FYM+ Glomus intraradices. Giri et al., (2005) found highest mycorrhizal dependency when inoculated with Glomus intraradices in $C$. siamea seedling. Mycorrhizal dependency is extent at which a plant species relies on mycorrhizal symbiosis for producing maximum biomass at a given level of soil fertility reported by Barua et al., (2010) in Gmelina arborea, Jha et al., (2017) in Jatropha curcas L. Shukla et al., (2012) in Eucalyptus tereticornis. 
Table.1 Growth parameters of Ailanthus excelsa seedlings after six months of sowing

\begin{tabular}{|c|c|c|c|c|c|c|c|c|c|c|c|c|c|c|c|c|}
\hline \multirow[t]{2}{*}{ Treatments } & \multicolumn{8}{|c|}{ After 3 months } & \multicolumn{8}{|c|}{ After 6 month } \\
\hline & $\begin{array}{c}\text { Root } \\
\text { length } \\
(\mathrm{cm})\end{array}$ & $\begin{array}{c}\text { Fresh } \\
\text { root } \\
\text { weight } \\
\text { (g) }\end{array}$ & $\begin{array}{l}\text { Dry } \\
\text { Root } \\
\text { eight } \\
(g)\end{array}$ & $\begin{array}{c}\text { Shoot } \\
\text { Length } \\
\text { (cm) }\end{array}$ & $\begin{array}{l}\text { Fresh } \\
\text { Shoot } \\
\text { weight } \\
\text { (g) }\end{array}$ & $\begin{array}{c}\text { Dry } \\
\text { Shoot } \\
\text { weight } \\
\text { (g) }\end{array}$ & $\begin{array}{c}\text { Collar } \\
\text { diameter } \\
(\mathbf{m m})\end{array}$ & $\begin{array}{c}\text { Number } \\
\text { of } \\
\text { leaves/ } \\
\text { plant }\end{array}$ & $\begin{array}{c}\text { Root } \\
\text { length } \\
(\mathrm{cm})\end{array}$ & $\begin{array}{c}\text { Fresh } \\
\text { root } \\
\text { weight } \\
\text { (g) }\end{array}$ & $\begin{array}{c}\text { Dry } \\
\text { Root } \\
\text { Weight } \\
\text { (g) }\end{array}$ & $\begin{array}{c}\text { Shoot } \\
\text { Length } \\
\text { (cm) }\end{array}$ & $\begin{array}{l}\text { Fresh } \\
\text { Shoot } \\
\text { weight } \\
\text { (g) }\end{array}$ & $\begin{array}{c}\text { Dry } \\
\text { Shoot } \\
\text { weight } \\
\text { (g) }\end{array}$ & $\begin{array}{c}\text { Collar } \\
\text { diameter } \\
(\mathbf{m m})\end{array}$ & $\begin{array}{c}\text { Number } \\
\text { of } \\
\text { leaves/ } \\
\text { plant }\end{array}$ \\
\hline Contol (only FS), & 08.40 & 0.25 & 0.11 & 11.60 & 0.71 & 0.18 & 1.57 & 2 & 11.20 & 0.81 & 0.31 & 18.50 & 1.36 & 0.47 & 2.83 & 3 \\
\hline FS + G.I & 10.50 & 1.04 & 0.36 & 15.20 & 1.42 & 0.42 & 2.87 & 3 & 15.40 & 1.51 & 0.64 & 19.30 & 1.43 & 0.49 & 3.01 & 5 \\
\hline $\mathbf{F S}+\mathbf{A} . \mathbf{S}$ & 15.80 & 1.16 & 0.41 & 14.40 & 1.24 & 0.38 & 2.95 & 4 & 25.90 & 1.90 & 0.82 & 23.50 & 2.89 & 1.03 & 3.56 & 6 \\
\hline FS + FYM (1:1) & 16.30 & 0.48 & 0.19 & 13.30 & 0.67 & 0.23 & 2.53 & 3 & 17.30 & 2.07 & 0.98 & 24.60 & 3.40 & 1.22 & 3.62 & 5 \\
\hline FS + PS (1:1) & 10.10 & 0.41 & 0.16 & 12.60 & 0.58 & 0.19 & 2.34 & 3 & 12.20 & 2.92 & 1.37 & 23.50 & 2.90 & 1.04 & 3.79 & 5 \\
\hline $\begin{array}{l}\text { FS + FYM + G.I } \\
(1: 1)\end{array}$ & 18.90 & 0.95 & 0.68 & 21.10 & 1.84 & 0.65 & 3.72 & 5 & 27.40 & 5.87 & 2.59 & 37.60 & 11.65 & 4.13 & 7.12 & 8 \\
\hline $\begin{array}{l}\text { FS + FYM + A.S } \\
(1: 1)\end{array}$ & 27.50 & 2.32 & 0.84 & 20.00 & 1.62 & 0.56 & 3.42 & 4 & 36.30 & 6.23 & 3.38 & 32.60 & 8.38 & 2.66 & 6.90 & 7 \\
\hline $\begin{array}{l}\text { FS + PS + G.I } \\
(1: 1)\end{array}$ & 18.10 & 1.56 & 0.51 & 17.50 & 1.41 & 0.49 & 2.67 & 3 & 20.40 & 3.02 & 1.46 & 29.40 & 5.66 & 1.81 & 4.28 & 5 \\
\hline $\begin{array}{l}\text { FS + PS + A.S } \\
(1: 1)\end{array}$ & 19.70 & 1.68 & 0.56 & 15.20 & 1.28 & 0.38 & 2.75 & 3 & 25.10 & 4.18 & 1.82 & 26.10 & 4.18 & 1.24 & 5.12 & 5 \\
\hline $\begin{array}{l}\text { FS + PS + FYM + } \\
\text { G.I }(1: 1: 1)\end{array}$ & 18.50 & 1.52 & 0.54 & 19.50 & 1.58 & 0.53 & 3.34 & 4 & 22.50 & 5.45 & 1.85 & 31.20 & 7.94 & 2.50 & 5.64 & 6 \\
\hline $\begin{array}{l}\text { FS + PS + FYM + } \\
\text { A.S }(1: 1: 1)\end{array}$ & 19.80 & 1.87 & 0.66 & 18.50 & 1.44 & 0.49 & 2.77 & 3 & 24.80 & 5.68 & 2.11 & 30.50 & 7.66 & 2.42 & 6.04 & 5 \\
\hline $\begin{array}{l}\text { FS + PS + FYM + } \\
\text { A.S + G.I }(1: 1: 1)\end{array}$ & 09.80 & 0.56 & 0.14 & 12.50 & 0.88 & 0.22 & 2.22 & 3 & 12.30 & 1.23 & 0.74 & 22.40 & 2.75 & 0.98 & 3.44 & 4 \\
\hline CD at $5 \%$ & 02.34 & 0.14 & 0.11 & 01.89 & 0.15 & 0.09 & 0.62 & NS & 01.68 & 0.57 & 0.15 & 01.56 & 0.69 & 0.19 & 0.55 & 2.57 \\
\hline
\end{tabular}


Table.2 Colonization index, Mycorrhizal dependency and Seedling quality index of Ailanthus excelsa seedlings after six months of sowing

\begin{tabular}{|c|c|c|c|c|c|c|}
\hline \multirow[b]{2}{*}{ Treatments } & \multicolumn{3}{|c|}{ After 3 months } & \multicolumn{3}{|c|}{ After 6 month } \\
\hline & $\begin{array}{c}\text { Colonization } \\
\text { Index } \\
(\%)\end{array}$ & $\begin{array}{c}\text { Mycorrhizal } \\
\text { Dependency } \\
(\%)\end{array}$ & $\begin{array}{l}\text { Seedling } \\
\text { quality } \\
\text { index } \\
\text { (g/cm/mm) }\end{array}$ & $\begin{array}{l}\text { Colonization } \\
\text { Index } \\
(\%)\end{array}$ & $\begin{array}{c}\text { Mycorrhizal } \\
\text { Dependency } \\
(\%)\end{array}$ & $\begin{array}{l}\text { Seedling } \\
\text { quality } \\
\text { index } \\
\text { (g/cm/mm) }\end{array}$ \\
\hline Contol (only FS), & - & - & 0.020 & - & - & 0.065 \\
\hline FS + G.I & 19.88 & 62.82 & 0.077 & 26.50 & 30.97 & 0.092 \\
\hline $\mathbf{F S}+\mathbf{A} . \mathbf{S}$ & 18.13 & 63.29 & 0.071 & 24.88 & 57.84 & 0.122 \\
\hline FS + FYM (1:1) & - & - & 0.033 & - & - & 0.172 \\
\hline FS + PS (1:1) & - & - & 0.032 & - & - & 0.237 \\
\hline FS + FYM + G.I (1:1) & 33.75 & 78.20 & 0.113 & 41.25 & 88.39 & 0.627 \\
\hline FS + FYM + A.S (1:1) & 33.12 & 79.29 & 0.096 & 39.35 & 87.09 & 0.561 \\
\hline FS + PS + G.I (1:1) & 26.25 & 71.00 & 0.070 & 33.75 & 76.15 & 0.254 \\
\hline FS + PS + A.S (1:1) & 24.38 & 69.15 & 0.070 & 32.50 & 74.51 & 0.286 \\
\hline FS + PS + FYM + G.I (1:1:1) & 31.25 & 72.90 & 0.087 & 38.13 & 82.07 & 0.400 \\
\hline FS + PS + FYM + A.S $(1: 1: 1)$ & 30.88 & 74.78 & 0.079 & 36.25 & 82.78 & 0.440 \\
\hline $\begin{array}{l}\text { FS + PS + FYM + A.S + G.I } \\
(1: 1: 1)\end{array}$ & 18.88 & 19.44 & 0.031 & 24.38 & 54.65 & 0.151 \\
\hline CD at $5 \%$ & 02.41 & 05.78 & 0.005 & 02.90 & 05.25 & 0.059 \\
\hline
\end{tabular}


Singh and Chugh, (2019) found that seedlings of plants i.e., P.cineraira, D. sissoo, E. tereticornis, A. indica and A. excelsa grown in pots inoculated with mycorrhizae fungi performed significantly better that uninoculated soils. Jha et al., (2014) in Pongamia pinnata. Shukla et al., (2013) in Dalbergia sissoo. Seedling quality index reported highest in treatment Field soil+ FYM+ Glomus intraradices followed by Field soil+ FYM+ Acaulospora scrobiculata and found least in control. Seedling quality index can be a good indicator for the out planting performance of nursery raised seedlings, better nutrient availability reported by Tsakaldimi et al., (2009) and increase in quality index increases performance of plant Bayala et al., (2009). Further, Kaushik et al., (2003) reported that VAM inoculation increased $\mathrm{N}, \mathrm{P}$ and $\mathrm{K}$ concentration in roots and shoot in A. nilotica and D. sissoo. Similar results were observed by Kumar (2020) that seedlings of Dalbergia sisso which were grown in the pots containing AM fungi performed significantly better in terms of growth parameters than the seedlings which were grown in the pots with un-inoculated soils in all water treatments under studied.

In conclusion based on above mentioned results it may be concluded that potting media containing FS + FYM + G.I had stimulatory effect on shoot parameters, colonization index, mycorrhizal dependency and seedling quality index and the potting media containing FS + FYM + A.S had stimulator effect on root parameters i.e., root length, fresh root weight and dry root weight. Further, it was also observed that combinations of both the mycorrhizae under studied in potting media had significantly poor effect on all the parameters after three and six months of Ailantus exclesa seedlings growth under studied. Potting media containing FS + FYM performed better than containing FS + PS with mycorrhiza inoculum also observed during experimentation. Finally, it was recorded that potting media containing FS + FYM with individual mycorrhizal fungi performed better than control and other treatments under studied.

\section{References}

Ahmadloo, F., Tabari, M., Yousefzadeh, H., Kooch, Y. and Rahmani, A. (2012). Effect of soil nutrient status on seedling nursery performance of Arizona cypress (Cupressus arizonica var arizonica Greene) and Medite cypress (Cupressus sempervirens var. horizantalis (Mill.) Gord). African Journal of Plant Science. 6(4): 140-149.

Amit Kumar, R. S. Beniwal, M. K. Singh, Sandeep Arya and Rakesh Kumar Chugh. 2020. Effect of Glomus mosseae Inoculation on the Growth of Dalbergia sissoo Seedlings with Normal, Stress and Re-watering Conditions. Int.J.Curr.Microbiol.App.Sci. 9(06): 781786. doi: https://doi.org/10.20546/ijcmas.2020.906 .100

Annapurna, D., Rathore, T.S. and Joshi, G. (2007). Effect of potting medium ingredients and sieve size on the growth of seedlings of sandalwood (Santalum album L.) in root trainers. Indian Forester.133(2): 179-188.

Banerjee, K., Gadani, M.H., Srivastava, K.K., Verma, N., Jasrai, Y.T. and Jain, N.K. (2013). Screening of efficient arbuscular mycorrhizal fungi for Azadirachtaindica under nursery condition: a step towards afforestation of semi-arid region of Western India. Brazilian Journal of Microbiology.44(2): 587-594.

Barua, A., Gupta, S.D., Mridha, M.A.U. and Bhuiyan, M.K. (2010). Effect of arbuscular mycorrhizal fungi on growth of Gmelina arborea in arsenic- 
contaminated soil. Journal of Forestry Research.21(4): 423-432.

Basumatary, N., Parkash, V., Tamuli, A.K., Saikia, A.J. and Teron, R. (2014). Arbuscular mycorrhizal inoculation affects growth and rhizospheric nutrient availability in Heveabrasiliensis (Willd. ex A. Juss.) Mull. Arg. clones. International Journal of Current Biotechnology.2(7): 14-21.

Bayala, J., Dianda, Z.M., Wilson, Z.J., Ouedraogo, S.J. and Sanon, Z.K. (2009). Predicting field performance of five irrigated tree species using seedling quality assessment in Burkina Faso, West Africa, New Forest.38: 309-322.

Berdeni, D., Cotton, T.E.A., Daniell, T.J., Bidartondo, M., Cameron, D.D. and Evans, K.L. (2018). The effects of arbuscular mycorrhizal fungal colonisation on nutrient status, growth, productivity and canker resistance of apple (Malus pumila). Frontiers in Microbiology.9(1461): 1-14.

Bi, Y., Zhang, Y. and Zou, H. (2018). Plant growth and their root development after inoculation of arbuscular mycorrhizal fungi in coal mine subsided areas. International Journal of Coal Science \& Technology.5(1): 47-53.

Biradar, A.P., Devarnavadgi, S.B. and Sunitha, N.D. (2001). Effect of vermicompost as potting mediamixture on growth and vigour of neem seedlings. Karnataka Journal of Agricultural Sciences. 14(2): 512-513.

Bhasotiya, H.C. and Tandel, M.B. (2017). Influence of potting mixtures on germination, growth and survival of Ailanthus excelsa.Trends in Biosciences. 10(3): 1122-1124.

Chen, M., Yang, G., Sheng, Y., Li, P., Qiu, H., Zhou, X., Huang, L. and Chao, Z. (2017). Glomus mosseae inoculation improves the root system architecture, photosynthetic efficiency and flavonoids accumulation of liquorice under nutrient stress. Frontiers in Plant Science.8(931): 1-10.

Chu, E.Y. (1999). The effects of arbuscular mycorrhizal fungi inoculation on Euterpe oleraceaMart.(AÇAÍ) seedlings. PesquisaAgropecuáriaBrasileira.34(6): 1018-1024.

Dell'Amico, J., Torrecillas, A., Rodriguez, P., Morte, A. and Sanchez-Blanco, M.J. (2002). Responses of tomato plants associated with the arbuscular mycorrhizal fungus Glomus clarum during drought and recovery. The Journal of Agricultural Science.138(4): 387-393.

Dickson, A., Leaf, A.L. and Hosner, J.F. (1960). Quality appraisal of white spruce and white pine seedling stock in nurseries. The Forestry Chronicle.36(1): $10-13$.

Filho, J.A.V., Mendonça Freitas, M.S., Martins, M.A., dos Santos, P.C. and Cordeiro de Carvalho, A.J. (2017). Arbuscular mycorrhizal fungi and phosphate fertilization on star fruit tree seedlings. RevistaBrasileira de CiênciasAgrárias.12(1): 14-19.

Genre, A. and Bonfante, P. (2010). The making of symbiotic cells in arbuscular mycorrhizal roots. In Arbuscular mycorrhizas: Physiology and function, pp. 57-71.

Ghosh, S. and Verma, N.K. (2011). Requirement of Arbuscular mycorrhizal (Glomus mosseae) inoculum for optimum growth of tree seedlings in lateritic soil. Indian Forester137(2): 243-248

Giovannetti, M. (2008). Structure, extent and functional significance of belowground arbuscular mycorrhizal networks. In: Varma, A. (Ed.) Mycorrhiza: State of the Art, Genetics and Molecular Biology, Eco-Function, Biotechnology, EcoPhysiology, Structure and Systematics. Third edition. Springer-Verlag,Berlin 
Heidelberg, pp. 59-72.

Giri, B., Kapoor, R. and Mukerji, K.G. (2005). Effect of the arbuscular mycorrhizae Glomus fasciculatum and $G$. macrocarpum on the growth and nutrient content of Cassia siamea in a semi-arid Indian wasteland soil. New Forests.29(1): 63-73.

Gosling, P., Hodge, A., Goodlass, G. and Bending, G.D. (2006). Arbuscular mycorrhizal fungi and organic farming. Agriculture, Ecosystems and Environment.113(1-4): 17-35.

Guissou, T., Babana, A.H., Sanon, K.B. and Ba, A.M. (2016). Effects of arbuscular mycorrhizae on growth and mineral nutrition of greenhouse propagated fruit trees from diverse geographic provenances. Biotechnol. Agron. Soc. Environ. 20(3): 417-426.

Han, S.H., An, J.Y., Hwang, J., Kim, S.B. and Park, B.B. (2016). The effect of organic manure and chemical fertilizer on the growth and nutrient concentration of yellow poplar (Liriodendron tulipifera Lin.) in nursery system. Journal of Forest Science and Technology.12(3):137-143.

Ilangamudali, I. and Senarathne, S.H.S. (2016). Effectiveness of Arbuscular Mycorrhizal Fungi based biofertilizer on early growth of coconut seedlings. The Journal of the Coconut Research Institute of Sri Lanka.22: 01-12.

Jasper, D.A., Abott, L.K. and Robbinson, A.D. (1989). Acacias response to addition of phosphorus and to inoculations with VA mycorrhiza fungi in soil stockpile during mineral sand and mining. Plant and Soil.115: 99-108.

Jat, H.S., Singh R.K. and Mann, J.S. (2011). Ardu (Ailanthus sp.) in arid ecosystem: A compatible species for combating with drought and securing livelihood security of resource poor people. Indian Journal of Traditional Knowledge.10: 102-113.
Jha, A., Kamalvanshi, M., Kumar, A., Chakravarthy, N., Shukla. A. and Dhyani, S.K. (2014). The effect of arbuscular mycorrhizal inoculations and cotyledon removal on early seedling growth of Pongamiapinnata. Turk. J. Bot. 38: 526-535.

Kaushik, J.C.; Dabas, P. and Kumar, R. (2000).lmpact of Glomus mosseae inoculation on root pathogens in Acacia nilotica and Dalbergia sissoo seedlings. Indian J. Forestry, 23 (3): 238-240

Kaushik, J.C.; Dabas, P. and Kumar, R. (2003). Influence of Glomus mosseae, Phosphorus and drought stress on the nodulation and nutrient content of Acacia nilotica and Dalbergia sissoo seedlings. Indian J. Forestry, 26(1): 11-13.

Kumar, A.; Beniwal, R. S.; Singh, M. K.; Arya, S.and Chugh. R. K. (2020). Effect of Glomus mosseae Inoculation on the Growth of Dalbergia sissoo Seedlings with Normal, Stress and Re-watering Conditions. Int.J.Curr.Microbiol.App.Sci. 9(06): 781-786.

Mehrotra, M.D., Khan, S.N. and Uniyal, K. (1999). Study on the impact of mycorrhizal and fertilizer on the growth of bamboo. Indian J. For. 6: 118-123.

Miransari, M. (2010). Contribution of arbuscular mycorrhizal symbiosis to plant growth under different types of soil stress. Plant Biology.12(4): 563-569.

Mohan, V. and Sandeep, C. (2015). Biochemical analysis and growth enhancement studies of important medicinal plant, Rauvolfiaserpentina inoculated with Arbuscular Mycorrhiza fungi in nursery. International Journal of Current Microbiology and Applied Sciences.4(6): 811-820.

Mulugeta, G. (2014). Effect of different potting mixture on the seedling growth and survival of Albiziagummiferaand Cordia Africana. Journal of Natural Sciences Research.4(3): 25-33. 
Mwangi, R.W., Kariuki, S.T. and Wagara, I.N. (2017). Effect of inoculation with mycorrhizae on growth parameters of Donbeya torrid, Leucaena leucocephala and Tephrosiavogelii. Journal of Natural Sciences Research.7(10): 40-48.

Phillips, J.M. and Hayman, D.S. (1970). Improved procedures for clearing roots and staining parasitic and vesiculararbuscular mycorrhizal fungi for rapid assessment of infection. Transactions of the British Mycological Society.55(1): 158-161.

Plenchette, C., Fortin, J.A. and Furlan, V. (1983). Growth responses of several plant species to mycorrhizae in a soil of moderate P-fertility. Plant and Soil.70(2): 199-209.

Saritha, B., Panneerselvam, P., Mohandas, S., Sulladmath, V.V. and Ravindrababu, P. (2014). Studies on host preference of Glomus sp and their synergistic effect on sapota (Manilkaraachras Mill. Forsberg) seedlings growth. Plant Arch.14(2): 701706.

Shukla, A., Kumar, A., Chaturvedi, O.P., Nagori, T., Kumar, N. and Gupta, A. (2017). Efficacy of rhizobial and phosphate-solubilizing bacteria and arbuscular mycorrhizal fungi to ameliorate shade response on six pulse crops. Agroforestry systems.92(2): 499509.

Shukla, A., Kumar, A., Jha, A. and Rao, D.V.K.N. (2012). Phosphorus threshold for arbuscular mycorrhizal colonization of crops and tree seedlings. Biology and Fertility of Soils.48(1): 109-116.

Shukla, A., Vyas, D. and Jha, A. (2013). Soil depth: and overriding factor for distribution of arbuscular mycorrhizal fungi. Journal of Soil Science and Plant Nutrition. 13(1): 23-33.

Singh, M.K and Chugh, R.K (2019). Impact of Arbuscular Mycorrhizal fungi on the growth parameters and nutrient content on different tree species. Ind. J. Pure App. Biosci., 7(6): 244-248.

Tsakaldimi, M., Tsitsoni, T., Ganatsas, P. and Zagas, T. (2009). A comparison of root architecture and shoot morphology between naturally regenerated and container grown seedlings of Quercus ilex. Plant Soil.324: 103-113.

\section{How to cite this article:}

Ishwar Anand, M. K. Singh, R. K. Chugh and Sanjay Kumar. 2020. Effect of Mycorrhizal Fungi on the Growth of Ailanthus excelsa Seedlings Grown in Different Potting Media under Nursery Condition. Int.J.Curr.Microbiol.App.Sci. 9(07): 1913-1922. doi: https://doi.org/10.20546/ijcmas.2020.907.218 